\title{
Dokument
}

\section{Den kaukasiske lakmusprøve: Konklusioner og konsekvenser}

Efterspillet efter den russisk-georgiske krig den 7. til 12. august 2008 fortsætter i skrivende stund, og dets nuancer ændres fra dag til dag. Nogle tentative konklusioner træder dog frem.

\section{Overordnede konklusioner}

Et lokalt krigsforløb andrer de globale strategiske spilleregler

Georgiens uløste konflikter bunder ganske vist i regionale og historiske problemer; men krigen illustrerer samtidig, at en enkelt begivenhed i Kaukasien kan udløse kræfter, som meget hurtigt forværrer den sikkerhedspolitiske situation i Europa, inklusive Østersøregionen.

Europas sikkerhedspolitiske situation forverres på grund af Ruslands optraden Det er ikke konflikten i sig selv som har udløst forværringen; men at Rusland har valgt at sænke sin tærskel for voldsanvendelse og valgt at

Det svenske Totalförsvarets Forskningsinstitut FOI har meget hurtigt udarbejdet en temmelig omfattende rapport om den russisk-georgiske krigs konsekvenser, og hvad man kan lære af forløbet. Titlen er "Den kaukasiske lakmusprøve”. FOI har haft en stor gruppe analytikere på opgaven, både civile forskere og officerer: Robert L. Larsson (red.), Alexander Atarodi, Eva Hagström Frisell, Jakob Hedenskog, Jerker Hellström, Jan Knoph, Vilhelm Konnander, Jan Leijonhielm, David Lindahl, Fredrik Lindvall, Johannes Malminen, Ingmar Oldberg, Fredrik Westerlund og Mike Winnerstig. Rapporten udkom i september. Den omfatter 155 sider, hvoraf 10 sider med kort og bilag og 22 sider med i alt 326 noter og henvisninger.

Da det kan være af interesse at se, hvordan forløbet vurderes af kyndige folk i vort (endnu) ikke-allierede naboland, bringer vi her rapportens konklusioner, oversat fra rapportens side 9-12. Rapporten kan hentes gratis som PDF-fil på www.foi.se, hvor man under Publikationer søger efter FOI-R-2563-SE 
ændre spillereglerne for internationalt samkvem. Selv hvis Georgien indledte krigshandlingerne mod Sydossetien, er det således et underordnet problem for omverdenen.

Rusland udfordrer verden - verdenssamfundets mekanismer lammes

Den russiske holdning udfordrer direkte den eksisterende verdensorden og indleder dermed en ny fase i russisk udenrigspolitik. Dette vil føre til omfattende policyændringer og tiltag hos flere aktører. De mekanismer og international fora, som skulle håndtere sikkerhedspolitiske spørgsmål er blokeret efter Georgienkrigen. Der er faldet et skarpt lys på verdenssamfundets muligheder for at håndtere problemer og udfordringer, og de svar som er fremtvunget af Ruslands vejvalg påvirker den nye verdensordens karakter og funktionsmåde.

\section{Øvrige konklusioner og konsekvenser}

Krigen er en lakmusprøve på, hvilken vej Rusland går

Krigen viser, at Rusland har valgt sin vej og givet sig selv nye regler for international handling, inklusive retten til med væbnet magt at ændre statsgrænser i Europa, som Moskva tidligere har anerkendt. Dette bryder ikke med nogen trend, men ligger i forlængelse af den politik, som landet har ført i flere år. Trusler om magtanvendelse, politiske markerin- ger med militære midler og støtte til løsrivelse er forekommet tidligere. Derimod er krigen et tydeligt brud på en trend, idet Rusland har overtrådt et antal regler, som verdenssamfundet i fællesskab har bekendt sig til. Krigen er endvidere et brud for så vidt som Vesten nu omvurderer sit syn på de politiske rammer for russisk optræden.

For Rusland er en række incidenter endvidere lakmusprøver på, hvordan omverdenen reagerer på anvendelsen af forskellige udenrigspolitiske instrumenter. Ved at bruge energivåbnet mod SNG-stater, føre cyberkrig mod Estland, sende flere bombeangreb mod Georgien i 2007 og invadere det i 2008 har Rusland afprøvet et antal tvangsmidler, heriblandt senest militær vold. Omverdenens reaktioner har vist, hvad Rusland kan tillade sig uden at møde andet end verbal modstand. Erfaringen med hvad der venter Rusland, når det anvender tvangsmidler, vil næppe lægge nogen dæmper på dets fremtidige optræden.

I et russisk perspektiv er konklusionen på krigen at omverdenen dels ikke kan eller vil påtvinge Rusland en hæmmende høj omkostning ved dets optræden, dels ikke er villig til at ofre ret meget for at påvirke Rusland. At EU fordømmer den russiske optræden en halv måned efter krigens afslutning, påvirker sandsynligvis ikke de russiske omkostningskalkyler i fremtiden. 
Ruslands oplevelse af succes kan blive ris til egen ryg

I et militært perspektiv var den russiske indsats kun delvis vellykket. Det faktum at man efter nogle dage besejrede de talmæssigt underlegne georgiske styrker og fremtvang en fred på egne vilkår, får ikke desto mindre russerne til at konkludere, at indsatsen gik godt. Det indebærer, at den russiske opfattelse af begivenhederne er forbundet med en følelse af succes, hvilket støtter en fortsat selvsikker optræden, ikke mindst når det gælder den fremtidige optræden over for stater i Ruslands nærområde.

Det faktum at den reelle internationale støtte til Georgiens forsvar, mens krigen stod på, var meget begrænset, antages også at have medført, at russerne har konkluderet, at hverken NATO eller EU kunne eller ville handle for at forhindre det, som skete. Det efterfølgende diplomatiske spil betragtes i Moskva ikke som et alvorligt modtræk fra Vesten. Diplomatiske udspil mener man at kunne leve med. Det er kun konkret handling man respekterer og indretter sig efter.

Oplevelsen af succes og oplevelsen af en trussel fra Vesten fører formodentlig til, at Rusland yderligere øger sin satsning på forsvar og sikkerhed. Rusland er dermed på vej ind i en sovjetisk fælde, hvor fokuseringen på sikkerhed mere og mere glider i retning af en militarisering af samfundet. Underliggende russi- ske problemer med en faldende rubel og på sigt en ustabil økonomi med tænkelig social uro til følge betyder, at den selvskabte isolationistiske holdning kan blive modproduktiv.

Rusland er ikke så stærkt som dets regime tilsyneladende tror. Faktisk svaghed i kombination med overdreven selvsikkerhed kan resultere i en uforudsigelig politik. Det, der i et vestligt perspektiv virker irrationelt og modproduktivt, er imidlertid ingen hindring for fortsat optræden i samme retning. Fremtidig russisk politik over for Ukraine og Moldova er indikatorer på, hvor langt Rusland vil gå ad den vej, det er slået ind på.

NATO står ved en skillevej, og USA andrer sit syn på Rusland Begivenhederne har stillet flere af NATOs kernespørgsmål på spidsen. Blandt de mere vigtige er, hvad et NATO-medlemskab indebærer, og hvad alliancens gensidige forsvarsforpligtelse betyder. Ikke mindst ved NATOs snarlige 60-årsjubilæum i 2009 må man regne med, at alliancens stilling til strategiske spørgsmål kommer på dagsordenen.

NATOs vejvalg vil til en begyndelse blive afprøvet på topmødet i december 2008, hvor tidspunktet for at give en MAP (Membership Action Plan) til Georgien og Ukraine står på dagsordenen. En anden prøve er, hvordan NATO vil stille sig til flere medlemmers krav om, at sikkerheds- 
garantierne får mere konkrete former. Der kan sandsynligvis blive tale om øgede investeringer i militær infrastruktur og øget militær aktivitet i alliancens østlige medlemslande

NATO må forholde sig til et skeptisk og måske konfrontatorisk Rusland. Et konsolideret og stærkt NATO har sikkert mulighed for at bevare og uddybe relationerne til Rusland. Et udestående spørgsmål er hvilket konkret svar Rusland giver på en eventuel ny udvidelse af NATO. Der er en risiko for, at alliancen og Rusland kommer på konfrontationskurs.

Forhåbninger knyttet til 'den nye verdensorden' har i to årtier præget USA's syn på Europa og Rusland. Under Georgienkrisen ændrede Washington politik og erklærede, at Rusland ikke længere er en pålidelig partner. Hvilke konsekvenser dette får for samarbejde med Rusland over for Kina eller Iran, vil fremtiden vise. Fra og med 2009 vil amerikanske soldater for første gang blive permanent stationeret i et tidligere Warszawapagtland.

\section{Konflikten uddyber problemer og kløfter $i$ og uden for Europa}

Selv om Rusland folkeretsligt har betalt en lav pris for sin indgriben, indebærer den en direkte konflikt med politiske og til dels også normative opfattelser i Europa. Ruslands beredvillighed til magtudøvelse og brud på suverænitetsprincippet lig- ger ikke på linje med opfattelsen i andre europæiske stater.

Kløften mellem Rusland og Europa illustreres endvidere af, at den europæiske politik med integration og tillidsskabelse ikke har kunnet påvirke Rusland i europæisk retning. Rusland ser ikke europæisering som en vej fremad, eftersom Rusland har andre forestillinger end Europa om endemålet for samarbejdet.

Dermed udfordres EU's rolle som udenrigspolitisk aktør. Skillelinjerne mellem Europas stater, som har forskellige erfaringer med og forskellige grader af energiafhængighed af Rusland, er den største udfordring for en fælles Ruslandspolitik i EU. Det komplicerer dialogen og mindsker muligheden for at påvirke Rusland. Men samtidig medfører Europas mæglerrolle i konflikten og uklarhederne i sekspunktaftalen et øget ansvar for den fortsatte løsning af konflikten.

Europas sikkerhedsarkitektur er i høj grad blevet bygget på et antal aftaler og rustningskontrolregimer. Disse smuldrer nu hurtigere end ventet på grund af krigen og dens eftervirkninger. På den baggrund kan Europa ikke længere stole på, at disse aftaler kan udgøre faste hjørnesten i sikkerhedspolitikken.

\section{Oversat fra svensk af Klaus Carsten} Pedersen 